\title{
Assessing the Funding and Quality of Education in Public Primary Schools in Mali
}

\author{
Abou Sidibé1, Wei Gao², Lala Jaiteh ${ }^{3}$ \\ ${ }^{1}$ School of Education, Central China Normal University, Wuhan, China \\ ${ }^{2}$ Department of Education, Central China Normal University, Wuhan, China \\ ${ }^{3}$ Ministry of Higher Education, Research, Science and Technology, Serrekunda, Gambia \\ Email: sidibe83abou@gmail.com
}

How to cite this paper: Sidibé, A., Gao, W., \& Jaiteh, L. (2022). Assessing the Funding and Quality of Education in Public Primary Schools in Mali. Open Journal of Social Sciences, 10, 487-501.

https://doi.org/10.4236/jss.2022.101036

Received: December 3, 2021

Accepted: January 26, 2022

Published: January 29, 2022

Copyright $\odot 2022$ by author(s) and Scientific Research Publishing Inc. This work is licensed under the Creative Commons Attribution International License (CC BY 4.0).

http://creativecommons.org/licenses/by/4.0/

\begin{abstract}
Malian primary education has been suffering from funding inadequacies over the past two decades, negatively affecting the school's learning outcomes. At the same time, several studies on school funding conducted in Mali continue to drive the school stakeholders' attention to the drawback of school funding inadequacies on the quality of education. After a few decades, the percentage of the country's GDP allocated to the education sector continues to rise and exceeds the state's financial capacity and affects the quality of education in public primary schools in Mali. Based on this fact, this study examines the impact of these funding inadequacies on learning and teaching outcomes of public primary school students. We used a secondary data collection technique to collect the data. We extracted data from government expenditure from 1992 to 2020. World Bank and OECD report documents to answer four fundamental questions related to the impact of school finance inadequacies on the quality of public primary schools in Mali. First question: what are the Malian public primary education main sources of funding? Second, what are the financial discrepancies of the public primary schools in Mali? Third, what are the effects of these financial discrepancies on the quality of education in public primary schools in Mali? Fourth, is the current budget allocated to primary education adequate to offer a mass and quality education? Our results indicated that: 1) The government is the leading funder of public primary education in Mali, followed by external donors and local funders. 2) Insufficiency and mismanagement of funds are the main financial discrepancies. 3) Those discrepancies have resulted in poor quality education (low completion rate, high school dropout, poor performance, low learning outcome.). 4) No. The current budget allocated to public primary schools is not sufficient enough to have a mass and quality education.
\end{abstract}




\section{Keywords}

Public Expenditure, Education Funding, Education Quality

\section{Introduction}

In the drive to make education affordable and accessible for every child, the Malian government, through the Department of Basic and Secondary Education, has embarked on massive educational reforms since independence in 1962 (Loua, 2017), where it has pledged to offer a mass and quality education to all its citizens. To achieve this goal, the Malian government has ratified the Convention of the Conference on Education for All (EFA) in Thailand (Jomtien) 1990, which clearly states its opinions that "an expanded vision of primary education was needed that would exceed the current resource levels, institutional structures, curricula, and standard delivery systems while building on the best current practices" (WCEFA Declaration, 1990, a newspaper Adult Education and Development (AED)). In 2000, the Millennium Development Goal (MDG) was launched in Dakar, where 164 countries pledged to meet basic educational needs, universalize access to education, and promote equity in education by 2015 (Wolfensohn, 2000).

Following the educational reforms, the government of Mali, through the Ministry of Basic and Secondary Education, has engaged in massive recruitment of school-going children from Age 7, which lead to a tremendous increase in the enrolment rate. From 1999 to 2000 and 2015 to 2016, The gross register rate (GER) rose from 1.7 percent to 4.4 percent in pre-school, from 57.4 percent to 77 percent in the primary, from 21.5 percent to 54.2 percent in lower secondary, and from 7.4 percent to 17.7 percent in general secondary education (World Bank, 2019a). In 2017, Mali allocated 19.9 percent of its budget to education. Per capita spending dropped by 19 percent in 2013; it has been rising by 3 percent per year since, but the total allocation has not yet reached its 22.4 percent high point of 2012 (Turner et al., 2019).

Because of this dramatic situation, the existing school's facilities and resources became inadequate to cater to the growing school population (Pearce et al., 2009: p. 7). While the quantitative expansion is impressive, the government of Mali must cope with numerous obstacles in dealing with increased social pressure for the development of primary education and the limited resources available to improve quality and learning outcomes for its citizens (UNESCO, 2011: p. 8). Therefore, the need to build new classroom facilities, recruitment and training of new teachers became a more significant challenge in providing quality educational services to society, especially those disadvantaged children living in the remote corners of the country (Pearce et al., 2009: p. 8., UNICEF, 2017).

Against all expectations, the government of Mali is witnessing a flood of difficulties, ranging from political, economic, technical, and mainly financial chal- 
lenges that have increasingly affected Mali's education system (Pearce et al., 2009). These include offering good living, working, and learning conditions, leading to recurrent teacher strikes, the inadequacy of classroom space, the inability to recruit qualified teachers, and inadequate teaching materials. The funding inadequacies of public primary schools in Mali are accumulating at a rapid pace. They affect the quality of the Malian education system, raising serious questions about how the financial resources allocated to the education sector are distributed and managed. The educationalists and the state authorities have always pointed to inadequate funding of education as one of the leading causes of this low performance of primary education in Mali. Year after year, the cost of primary education and the need to settle a solid financial system of funding has raised a lot of interest from educational policymakers and the political authorities of Mali.

This paper seeks to critically assess the underlying factors surrounding the issues of school funding and distribution process of public primary schools' resources in Mali and examine the correlation between the resources spent in the education sector and the quality of learning outcomes. The paper focuses on four main components: the cost of public primary education in Mali, the nature of primary education funding, the system of funding, the causes of the funding discrepancies, and a comparison between the budget and the quality of education outcomes. As the saying goes, it is one thing to ensure everyone has access to school, but it is another thing to ensure the quality of the trained human resources.

\section{Literature Review and Theoretical Framework}

Education funding has been and continues to be a general concern for all education systems and the backbone of all educational planning. The government's potential to provide quality education and plan new priorities depends on the abundance of adequate funding for education. The school funding management mechanism, distribution, and monitoring play an essential role in ensuring that resources are injected into their right portfolio (OECD, 2017). A flawed education funding system has deprived many African children's right to receive education, especially in sub-Saharan African countries. Mali is not an exception, which leads to many problems and shortcomings such as unclear funding system, dysfunctional educational funding, poor quality graduates. This situation has encountered considerable concern in literary analysis and assessment from many scholars. A school system that deficiencies quality teachers and school leaders, adequate infrastructure, and textbooks will have more difficulties promoting quality education (OECD, 2012a).

Schultz (1987) applied Human Capital theory to frame the relationship between the investment in education and the quality of human resources. In today's world, education is considered an economical device that is human capital. "The more we invest money in education, the more efficient labors will be got." 
(Schultz, 1987). "Empirical microeconomic studies have simultaneously refined and extended the base of evidence that the more educated individuals are, the more income they receive and produce more output than the less educated in a wide range of activities" (Schultz, 1987).

Similarly, Schultz (1987) revealed that good quality education in terms of learning outcomes in literacy, numeracy, and life skills could increase work productivity, higher individual income level, economic and social growth, health improvement, and innovative ideas. Education systems should provide adequate resources to ensure that all students have the opportunity to receive a high-quality primary education (Berne \& Stiefel, 1984). According to (UNESCO, 2011), providing quality education to an expanding student population requires resource use efficiency, and an assessment of cost-efficiency requires reliable financial data. Good governance is also mentioned a lot through different researches (Tsang, 1988). Rajkumar \& Swaroop (2008) noted that simply allocating public resources for suitable goods and services may not lead to desired outcomes if good governance is lacking. The efficiency of education internally or externally can be promoted by "technical" and "economic" means (Tsang, 1988). Others focus on the proper financing of education, equity, and inadequacy by examining spending and resource distribution in education, policy, and programming related to education finance mechanisms and equity-oriented resource redistribution, education inequality, and the economy. At the same time, OECD (2017) states that educational effectiveness refers to the potential of a particular combination of school resources to provide desired outcomes.

The Human capital theory indicates that education increases people's general mental capabilities and technical skills, increasing their productive potential in the labor force. High-quality education is required to make a significant contribution to economic growth and development (Almendarez, 2011). It follows that school is an investment and that people are an essential reservoir of capital and not merely a source of raw labor. Education contributes a tremendous and substantial role in the economic development of a nation. Thus educational expenditures constitute a form of investment. This augments an individual's human capital, leads to a greater output for society, and enhances earnings for the individual worker. It increases their employment opportunities in the labor market, allows them to reap pecuniary and non-pecuniary returns, and gives them a chance for job mobility (Almendarez, 2011). A well-design school funding policy is crucial to achieving quality, equity, and efficiency objectives in school education (OECD, 2012b).

So, there is this relationship between the robust funding of education and the quality of human capital. Over the years, the concept of human resources development has evolved from solely focusing on heavy investment in human capital development. The focus has been on how nation-states can produce quality human capital relevant to national development. Education exploits the skills and knowledge of its citizens and contributes to the country's socio-economic de- 
velopment.

Investment in education is an investment in human capital. Today sub-Saharan African countries, especially Mali, are concerned with issues regarding educational funding.

My interest in assessing the funding source in public primary schools in Mali arises because of the poor quality of students' performance in different exams and evaluations, the inadequate working conditions of both teachers and students, the insufficiency of reading and learning material teaching building, and teachers' quantity. So given the above, I would like to take this opportunity to critically assess and explore more about the funding of primary schools in Mali and contribute to the existing literature. To identify the correlation between the resources injected in education and the quality of education attained by the primary schools' graduates, scrutinize the primary school funding governance, distribution, and monitoring mechanism.

\section{Methodology}

The data collection method explored for this study is a secondary data collection technique, again called archival study. The practicality of utilizing existing data for research is becoming more prevalent (Smith et al., 2011). The use of existing data for research consists of reading and analyzing the contents of books, articles, journals, reports. The data are from the statistics collected by governments, international organizations (World Bank, UNESCO, UNICEF, OECD). We used ongoing inductive and interpretive strategies to identify and analyze documents.

The study embraces the interpretivist views. Its interpretivist view considers that reality is influenced by the social environment, open to manipulation. Documents must be seen in their social context and attempt to make sense of that.

\section{Eligibility}

The documents explored and scrutinized for this study are mainly on Malian government funding mechanism on primary education from 1992 to 2020. The materials used in answering our research questions were drawn from scholarly materials written on school funding between the period of 1992 to 2020. Similarly, other international documents, articles and scholarly materials written on school funding were also explored concomitantly.

Table 1 below illustrates the name of the authors, year of applications, methods of research design, and data source.

\section{Source and Process of Research}

During the study, google, google scholar, J store, ResearchGate, Eric's website was explored as my primary search engine for the reading materials. I have screened over one hundred (100) documents on board. Out of this, only fifty (50) documents were related to my topic. The most relevant of these fifty 
Table 1. Literature review assessment table.

\begin{tabular}{|c|c|c|c|}
\hline Name of Authors & $\begin{array}{l}\text { Year of } \\
\text { Publication }\end{array}$ & $\begin{array}{l}\text { Methods of } \\
\text { Research Design }\end{array}$ & Data Source \\
\hline Loua, S. & 2017 & Documentary & $\begin{array}{l}\frac{\text { https://documents1.worldbank.org/curated/en/1593715513 }}{\text { 63122855/pdf/Concept-Project-Information-Document-PI }} \\
\underline{\text { D-Mali-Education-Quality-for-Improved-Learning-Project }} \\
\underline{\text {-P168786.pdf }}\end{array}$ \\
\hline Almendarez, L. & 2011 & Documentary studies & $\underline{\text { https://doi.org/10.1080/00086495.2013.11672495 }}$ \\
\hline $\begin{array}{l}\text { Ministry of economics } \\
\text { and finance Mali: Annex } \\
\text { to the finance law } 2020 \text {. }\end{array}$ & 2019 & Finance program & $\underline{\text { https://budget.gouv.ml/sites/default/files/DPPD-PAP\%202 }}$ \\
\hline Diarra, M. C. & 1992 & $\begin{array}{l}\text { Synthesis of three Case } \\
\text { Studies }\end{array}$ & $\begin{array}{l}\text { https://digitalcommons.lsu.edu/cgi/viewcontent.cgi?article } \\
=7477 \& \text { context=gradschool_disstheses }\end{array}$ \\
\hline World Bank & 2019. & Report & $\begin{array}{l}\frac{\text { https://documents1.worldbank.org/curated/en/1593715513 }}{\text { 63122855/pdf/Concept-Project-Information-Document-PI }} \\
\underline{\text { D-Mali-Education-Quality-for-Improved-Learning-Project }} \\
\underline{\text {-P168786.pdf }}\end{array}$ \\
\hline OECD & 2017 & Study & $\underline{\text { http://dx.doi.org/10.1787/9789264276147-en }}$ \\
\hline Pearce et al. & 2009 & Report & $\begin{array}{l}\text { https://www-cdn.oxfam.org/s3fs-public/file_attachments/d } \\
\underline{\text { elivering-education-for-all-mali-report-07-06-09_4.pdf }}\end{array}$ \\
\hline World Bank & 2020 & Empirical studies & $\begin{array}{l}\text { https://data.worldbank.org/indicator/SE.PRM.CMPT.FE.Z } \\
\underline{\text { S?locations=ML }}\end{array}$ \\
\hline Turner et al. & 2019 & Report & $\begin{array}{l}\text { https://www.globalpartnership.org/sites/default/files/docu } \\
\text { ment/file/2020-04-country-level-prospective-evaluations-m } \\
\underline{\text { ali.pdf }}\end{array}$ \\
\hline UNESCO & 2011 & Report & $\begin{array}{l}\text { http://uis.unesco.org/sites/default/files/documents/financin } \\
\text { g-education-in-sub-saharan-africameeting-the-challenges- } \\
\underline{\text { of-expansion-equity-and-quality-en_0.pdf }}\end{array}$ \\
\hline UNESCO & 2017 & Report & $\underline{\text { https://unesdoc.unesco.org/ark:/48223/pf0000367169/PDF/ }}$ \\
\hline
\end{tabular}

documents on the funding and quality of primary education in Mali totaled twenty-five (25) documents. The sources of these materials were obtained from the World Bank, UNESCO, The Department of Education of Mali, The Budget Speech of the Republic of Mali, and several other journals, articles, and publications related to the funding and quality of the education system in Mali.

\section{Results}

Through an intensive thorough review of several documents such as articles, journals, and publications written on the funding mechanism and the quality of primary education in Mali and Sub-Saharan African countries, our following research questions were answered as follow:

Question: No. 1

What are the main sources of funding for the Malian public primary educa- 
tion system?

After a rigorous analysis of various documents on education funding, our findings indicate three main sources of financing of Malian primary education: The Government, External funders, and the local funders.

Among the three primary funding sources for education in Mali, the most important is the central government financing through national and regional allocations.

Table 2 shows that the spending on primary education has skyrocketed from 2012 to 2017, although it experienced some fluctuation between 2014, 2015, and 2016.

Secondly, the second funding source is external assistance through bilateral and multilateral cooperation, consisting of loans, grants, technical assistance, and scholarships for studies or training abroad provided by foreign governments, international governmental organizations, and non-governmental organizations (NGOs). According to the International Development Cooperation of Japan (IDCJ, 2012), the amount of aid in the education sector by other FTPs (Financial, technical partners) was $€ 12,904,977$ in 2011 , and $€ 10,394,599$. The share of sectoral financial aid in all FTPs aid in 2012 is around 30\%, and that of other assistance, including project aid, occupies 70\%. Table 3 shows some of the different donors and the percentage of their education aid.

Table 3 details the external donors for the action plan budget displayed by the Technical and financial monitoring report for the year 2016. The table shows the execution rate of the funds allocated. See the definition of the abbreviations used in the table in the appendix.

The third source of funding is local tax money, such as the "Local and Regional Development Fund", local communities, and tax revenues from the Association des Parents d "Eleves (APE) parents" association's tax (school management committee). The APE tax rate represented 3000 CFA francs per student in urban areas and 2000 CFA francs in rural areas. The school uses this fund to buy chalks, erasers, and textbooks for teachers to repair some broken chairs and desks. In some cases, the local tax is used to pay the salary of some teachers in the community's count.

\section{Question No. 2}

What are the financial discrepancies of the public primary schools in Mali?

Parallel to the increase of current public expenditures on the national education sector up to 36.5 percent of Mali's state budget, it was difficult for the previous governments of Mali from 2000 to 2018 to implement adequate funding for primary education (See first World Bank, 2019a). Considerable demand from other public services on the limited, scarce resources of the country, macroeconomic conditions such as the decline in export revenues, the slower rate of economic growth, budget deficit, inflation, and the increasing debt service have been significant factors that have significantly restricted the availability of financial resources. 
Table 2. Expenditure on primary education (\% of government expenditure on education).

\begin{tabular}{ccccccccc}
\hline Years & 2010 & 2011 & 2012 & 2013 & 2014 & 2015 & 2016 & 2017 \\
\hline expenditure & 25.281 & 38.46 & 38.31 & 39.45 & 43.188 & 45.13 & $39.57 \%$ & $44.67 \%$ \\
\hline
\end{tabular}

Source: World Bank, 2020.

Table 3. Sources of financing with execution rates for action plans for 2016 (CFA millions).

\begin{tabular}{cccc}
\hline SOURCE & ALLOCATION & EXECUTION & EXECUTION RATE \\
\hline ABS & 5955 & 4662 & 78 percent \\
BUDGET NATIONAL & 44,360 & 27,259 & 61 percent \\
BSI EXT & 11,053 & 1262 & 11 percent \\
BSI INT & 8524 & 6319 & 74 percent \\
TOTAL INTERNAL & 69,892 & 39,502 & 56 percent \\
GPE & 1555 & 6905 & 444 percent \\
FONGIM & 50,162 & 48,924 & 98 percent \\
AFD & 1994 & 1865 & 94 percent \\
UNICEF & 3248 & 3247 & 100 percent \\
USAID & 9684 & 9840 & 102 percent \\
PAM & 4489 & 3146 & 70 percent \\
EU & 10,167 & 99 & 1.5 percent \\
BID & & & 375 \\
TOTAL 151,190 & & 74,401 & 92 percent \\
TOTAL EXTERNAL & 81,300 & 113,904 & 75 percent \\
\hline
\end{tabular}

Source: GPE 2020 (Turner, 2019).

In addition to the above mentioned, financial mismanagement was reported as one of the significant financial discrepancies handicapping the quality of education. The Auditor General's report in 2006 found that overall government department nearly $\$ 200 \mathrm{~m}$ (FCFA $103 \mathrm{bn}, € 157 \mathrm{~m}$ ) of government capital had gone missing. Almost 70 percent of which include outstanding or ungathered taxes, including cases involving swindling by private companies and by local or junior officials. A considerable amount of money went missing in the education sector: more than $\$ 6 \mathrm{~m}$ (FCFA $3.2 \mathrm{bn}, € 5 \mathrm{~m}$, or nearly 3 percent of the total cash unaccounted for) was lost through missing school textbooks were purchased but never delivered (Bureau du vérificateur General, 2006).

Question No. 3

What are the effects of these financial discrepancies on the quality of the public primary education in Mali?

There are critical concerns about the quality of the education system in Mali, ranging from low access rates, inadequate infrastructure facilities, insufficient equity, familiar unqualified teachers, and weak learning outcomes. 


\section{1) Low Access Rate}

The dream of achieving universal primary education for all Malian children by 2015 is still a far-fetch reality; despite definite improvements in the delivery of educational services since 1990, Mali still has one of the lowest enrolment rates in the world. According to official figures, more than 890,000 Malian children aged seven, 7 - 12-four in ten of the children of this age-are currently out of school. In 2018, approximately 1.9 million primary school-age children are out of school, which represent nearly 40 percent of the primary school-age population (World Bank, 2021), more than two (2) million children aged between 5 to 17 still do not attend school, and over half of Mali's young people aged 15 to 24 are not literate (UNICEF, 2020).

2) low completion rate

According to the ministry of education statistics 2016-2017, the gross admission rate to the second cycle is $39.9 \%$, the national completion rate second cycle to senior high school is $30 \%$. The completion rate of the first cycle is schematized in Figure 2. In Mali, nearly three out of ten children never enter school and a quarter of those who have accessed it will end their studies before completing the first cycle of the basics schools.

Figure 1 and Figure 2 show the trend of the completion rate of primary school children in Mali. It is noticeable that from 2006 to 2018, the completion of both female and male children in primary school in Mali is drastically low compared to the international norm of $100 \%$.

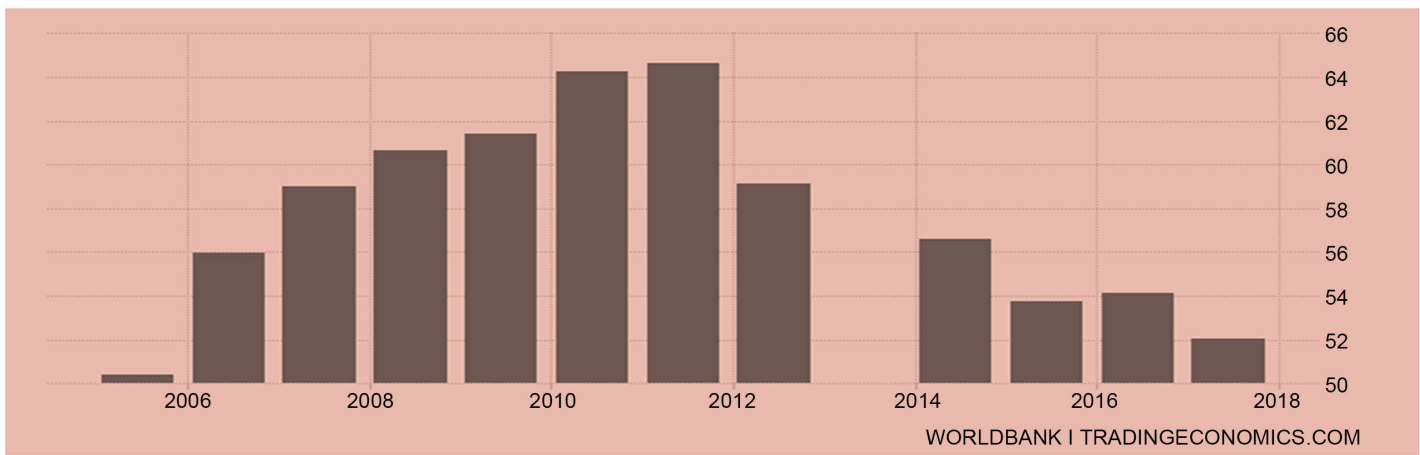

Figure 1. Mali-primary completion rate, male. Source: World Bank, 2020.

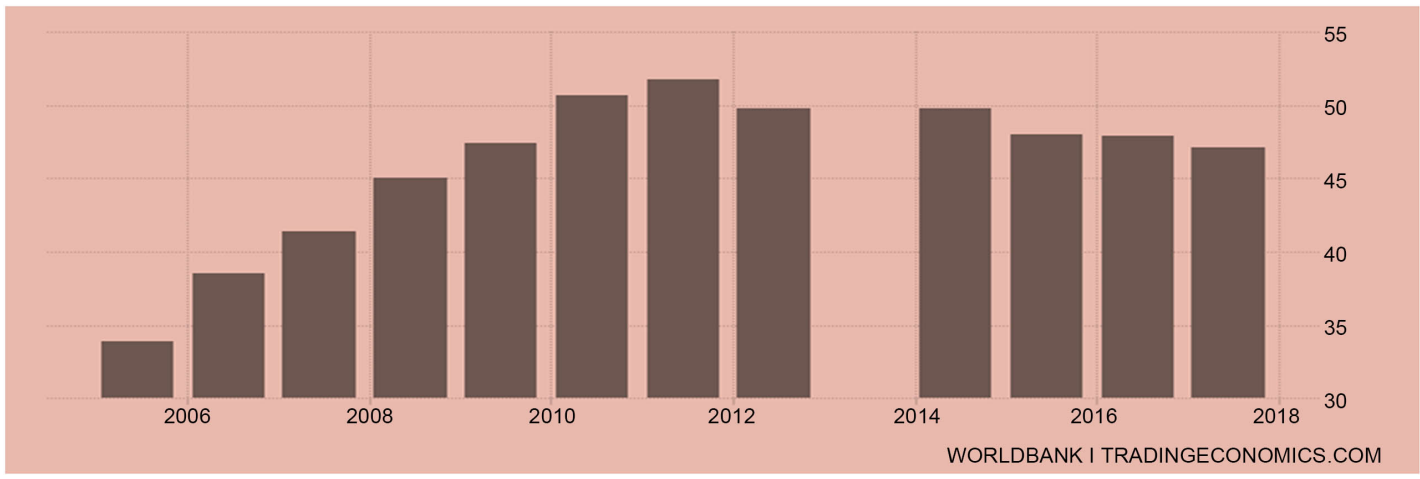

Figure 2. Mali-primary completion rate, female. Source: World Bank, 2020. 


\section{3) Poor Learning Outcomes (Low performance)}

After attesting the low completion rate, hundreds of pupils drop out of school before completing primary school. Among those who do complete, a large proportion fails to acquire desired levels of knowledge and skills, especially in the country's most impoverished areas.

According to the results from national and international assessments, for example, only 41 and 38 percent of second-grade students in Mali perform satisfactorily in reading comprehension and math's respectively, while the results of sixth-grade students are 48 percent in French and 31 percent in Math's, respectively. (PASEC assessments 2011-12 cited in World Bank, 2019a). Also, more than half of second-grade students and nearly 90 percent of fifth-grade students do not acquire the expected skills for their levels. One in every five Malian students in grade 2 cannot understand a series of simple sentences in writing and speaking. Two-thirds cannot perform several complex reading and writing tasks, and only a third of the students meet grade requirements (World Bank, 2019a). After two years of primary schooling, $61 \%$ of pupils had not yet developed minimal skills in sciences, math, and technology, and $51 \%$ of them had not acquired the minimum standards of reading and communication skills. (Thunnissen, 2009). In 2015, 70 percent of students from age group 6 - 14 were incapable of reading one word of a short story. In Mathematics, 10 percent did not answer any questions, 56.5 percent did not reach average proficiency (Turner et al., 2019)

\section{4) Inadequate school facilities}

Teaching and learning success is likely to be strongly influenced by the available resources to support the process and how these resources are properly utilized and managed. Key enabling inputs can be divided into material resources, human resources, and enabling administration or governance systems.

These grassroots assessments stipulate that children were sitting on the floor in about 12 percent of the classes observed on the day of the evaluation. In 18 percent of the classrooms, the capacity of the desks was holding more children than they are designed for. In 11 percent of the classrooms, the desks were broken or in disrepair, and in one out of every five classrooms. In 2014-15 all classrooms, only $73 \%$ of the 1 st cycle of the fundamental cycle and $88 \%$ of the 2 nd cycle establishments were in good condition (UNICEF, 2017).

\section{5) Low qualified teachers}

Table 4 shows the statistics of qualified teachers in basic schools in Mali from 2015-2018. It reveals that basic schools in Mali have a crisis of qualified teachers. In large part, this dates back to the World Bank and IMF structural adjustment reforms of the 1980s. Attempts to reduce the size of the civil service led to the resignation of around 1000 qualified teachers, or 12.5 percent of the teaching workforce. Reforms' to limit public spending saw five out of eight teacher training institutes (Institute pédagogique d'enseignement général) closed, leaving just three in the whole country. The combined effect-at a time when the aim was to expand universal primary education-was catastrophic. The challenge of restoring the teaching force and the sacrifices in teacher quality that it has entailed are 
Table 4. Statistics of qualified teachers in terms of quality, primary-level education is constrained by a lack of qualified teaching staff.

\begin{tabular}{ccccc}
\hline \multicolumn{5}{c}{ Qualified teachers in basic schools in Mali } \\
\hline Years & $\mathbf{2 0 1 5}$ & $\mathbf{2 0 1 6}$ & $\mathbf{2 0 1 7}$ & $\mathbf{2 0 1 8}$ \\
\hline Percentage & 25.3 & 30.6 & 35.9 & 41.2 \\
\hline
\end{tabular}

Source: Annexe au projet de loi de finances, 2020.

severe, and Mali is still feeling the effects of these disastrous structural adjustment programs (Maiga et al., 1995).

The pupil/teacher ratio remains high. On average, there is one teacher to every 51 pupils, although this rises to one to 64 in public schools, one to 76 in Bamako's public schools, and one to 100 in some schools (Pearce et al., 2009).

\section{Question No. 4}

Is the current budget allocated to primary education adequate to offer a mass and quality education in Mali?

When we compare the allocation of public funding in Mali to the corresponding average values in the countries of the sub-region, we note that the share attributed to primary education is low (35\% in Mali versus 50\% in the sub-region). With regards to the quality of education, the answer to the question is no. The current budget allocated to primary education is not adequate to provide mass and quality education. Looking at the nature of funding of primary education in Mali, we notice that the current budget is not adequate to provide mass and quality education for primary school children in Mali. Financial discrepancies are not the only issues affecting the quality of Malian primary schools' education. The challenges range from funds allocation and distribution process, monitoring and evaluation mechanism, and mismanagement of financial resources (World Bank, 2019b).

\section{Recommendations}

Even though the basic education of Mali continues to be the government's top priority, the performance in Malian public primary schools is generally deficient. In line with the 2030 education plan, all Malian girls and boys can have access to school and achieve the skills expected at the end of their schooling. This requires providing the minimum conditions for learning in all Malian primary schools, as recommended by the country's self-recommended quality repository. But this should not obscure the other dimensions that are more qualitative such as the ability to transform means into results must be seriously considered.

1) Governments must make difficult decisions about mobilizing and allocating resources in the current economic context, especially in light of rising demands from other public service sectors, such as infrastructure or health care.

2) The government should work to ensure that there is maximum transparency in the management of funding to the education sector. Strengthen governance across the industry at the central and decentralized levels to effectively 
transform resources into results.

3) The government should also create a central data-based system that will document all inflows of governments funds allocated to the education sector, to maintain an accurate account of all funds disbursed to public primary schools in Mali.

4) From this perspective, the procedures and mechanisms for allocating resources to schools and their applicability should be questioned to ensure that resources are adequately utilized. And they have reached where they need to be.

5) Current quality control devices should also be questioned to make them operational and effective at both the central and decentralized levels from a results-oriented management perspective. In general, the culture of results-led management should be inscribed in the habits at different levels of the chain of control accountability.

6) NGO education programs must be rooted in the priorities of government plans for education and implemented in partnership with and support decentralized authorities, helping them carry out their development plans and strengthen their ability to do this themselves.

\section{Conclusion}

The purpose of this study was to assess the funding and quality of education in public primary schools in Mali. Based on our findings, we conclude that Mali has experienced rapid enrollment at all education levels during the past decade. This mass intake raised particular challenges in meeting education for all (EFA) goals and ensuring sustainable educational development because of various external factors, including economic growth, resource mobilization, and governance. As a result of demographic pressure and steady increases in enrolment at primary and post-primary education levels, the demand for education continues to grow. In a context of persistent external constraints and a surging need for education, Mali faces financial limitations in providing quality education for all.

So, the need for better quality education also requires the allocation of more resources to the education sector, and financial constraints are likely to persist. However, the poor performance of Mali's education sector continues to directly relate to funding shortages and weaknesses in public management, mismanagement of the funds allocated to the industry of education. Mali needs more schools, more qualified teachers, and updated teaching materials. The satisfaction of these needs is linked to the availability of robust and sustainable funding.

Due to a lack of proper data recording and management system in place, it was difficult for the researcher to lay his hands on the first-hand statistics of the total funds and expenditure allocated to the sector. Therefore, the views expressed in this paper do not account for all the current challenges of funding and quality education in primary schools in Mali. Moreover, the use of a secondary data collection method may not have profound and detailed information through the experiences of those in charge of voting, distributing, and managing the funds allocated to the primary education sector in Mali. 


\section{Conflicts of Interest}

The authors declare no conflicts of interest regarding the publication of this paper.

\section{References}

Almendarez, L. (2011). Human Capital Theory: Implications for Educational Development. Caribbean Quarterly, 59, 21-33. https://doi.org/10.1080/00086495.2013.11672495

Annexe au projet de loi de finances (2020) document de programmation pluriannuelle des dépenses et projet annuel de performance DPPD-PAP 2020-2022. Ministère de l'Economie et des Finances, Mali. https://budget.gouv.ml/sites/default/files/DPPD-PAP\%202020-2022.pdf

Berne, R., \& Stiefel, L. (1984). The Measurement of Equity in School Finance: Conceptual, Methodological, and Empirical Dimensions. The Johns Hopkins University Press.

Bureau du vérificateur General (2006). Rapport Annuel 2006 (pp. 32-33). Office of the auditor General, Annual Report.

http://www.bvg-mali.org/images/Rapports/annuels/rapport_annuel_2006.pdf

International Development Center of Japan Inc. (IDCJ) (2012). Rapport D'analyse du Secteur de L'éducation de base [Basic Education Sector Analysis Report, August 2012]. https://openjicareport.jica.go.jp/pdf/12083291.pdf

Loua, S. (2017). Les grandes réformes de l'école malienne de 1962 à 2016. [Major Reforms of Malian Schools from 1962 to 2016]. Revue Internationale d'Education de Sèvres, 75, 34-40. https://doi.org/10.4000/ries.5917

Maiga, A. S., Teme, B., Coulibaly, B. S., Diarra, L., Kergna, A. O., Tigana, A., \& Winpenny, J. (1995). Structural Adjustment and Sustainable Development in Mali. Overseas Development Institute. https://www.cbd.int/financial/fiscalenviron/mali-structural.pdf

OECD (2012a). Education GPS: School Resources. https://gpseducation.oecd.org/revieweducationpolicies/\#!node=50589\&filter $=$ all

OECD (2012b). Equity and Quality in Education: Supporting Disadvantaged Students and Schools. OECD Publishing. https://www.oecd.org/education/school/50293148.pdf

OECD (2017). The Funding of School Education: Connecting Resources and Learning http://dx.doi.org/10.1787/9789264276147-en

Pearce, C., Fourmy, S., \& Kovach, H. (2009). Delivering Education for All in Mali, Oxfam International.

https://www-cdn.oxfam.org/s3fs-public/file_attachments/delivering-education-for-allmali-report-07-06-09_4.pdf

Rajkumar, A., \& Swaroop, V. (2008). Public Spending and Outcomes: Does Governance Matter? Journal of Development Economics, 86, 96-111.

https://doi.org/10.1016/j.jdeveco.2007.08.003

https://openknowledge.worldbank.org/bitstream/handle/10986/14248/multi0page.pdf? sequence $=1$ \&isAllowed $=y$

Schultz, T. (1987). Education Investment and Return in Economic Development. Yale University. https://www.econstor.eu/bitstream/10419/160451/1/cdp528.pdf

Smith, A. K., Ayanian, J. Z., Covinsky, K. E., Landon, B. E., McCarthy, E. P., Wee, C. C., \& Steinman, M. A. (2011). Conducting High-Value Secondary Dataset Analysis: An Introductory Guide and Resources. Journal of General Internal Medicine, 28, 920-929. https://doi.org/10.1007/s11606-010-1621-5

Thunnissen, K. (2009). Sector Budget Support in Practice: Case Study Education Sector in 
Mali (p. 6). Overseas Development Institute.

https://cdn.odi.org/media/documents/5806.pdf

Tsang, C. (1988). Cost Analysis for Educational Policymaking: A Review of Cost Studies in Education in Developing Countries. Review of Educational Research, 58, 181-230. https://doi.org/10.3102/00346543058002181

Turner, F., Tylor, G., \& Outhread (2019, April). GPE 2020 Country-Level Prospective Evaluations.

https://www.globalpartnership.org/sites/default/files/document/file/2020-04-country-le vel-prospective-evaluations-mali.pdf

UNICEF (2017). République du Mali: Analyse du secteur de l'éducation pour la relance d'un enseignement fondamental de qualité pour tous et le développement d'une formation adaptée aux besoins [Analysis of the Education Sector for the Revival of Quality Basic Education for All and the Development of Training Adapted to Needs]. https://unesdoc.unesco.org/ark:/48223/pf0000367169/PDF/367169fre.pdf.multi

UNICEF (2020). Harnessing Children'S Potential through Quality Education for Every Child. https://www.unicef.org/mali/en/education

United Nation Education Science and Culture Organization UNESCO (2011). Financing Education in Sub-Saharan Africa Meeting the Challenges of Expansion, Equity, and Quality (p. 22).

http://uis.unesco.org/sites/default/files/documents/financing-education-in-sub-saharan -africameeting-the-challenges-of-expansion-equity-and-quality-en_0.pdf

Wolfensohn, J. D. (2000). From Jomtien to Dakar, Meeting Basic Learning Needs. World Bank.

https://www.dvv-international.de/en/adult-education-and-development/editions/aed-5 $\underline{52000 / \text { dakar-education-for-all/from-jomtien-to-dakar-meeting-basic-learning-needs-n }}$ dash-of-whom

World Bank (2019a). Mali Education Quality for Improved Learning Project Information Document (PID) (p. 8).

https://documents1.worldbank.org/curated/en/159371551363122855/pdf/Concept-Proj ect-Information-Document-PID-Mali-Education-Quality-for-Improved-Learning-Proj ect-P168786.pdf

World Bank (2019b, April 26). International Development Association Project Appraisal Document on a Proposed Grant to the Republic of Mali for Deployment of State Resources for Better Service Delivery Project.

https://documents1.worldbank.org/curated/en/214081558922577300/pdf/Mali-Deploy ment-of-State-Resources-for-Better-Service-Delivery-Project.pdf

World Bank (2020). Mali-Primary Completion Rate, Male.

https://tradingeconomics.com/mali/primary-completion-rate-male-percent-of-relevant -age-group-wb-data.html

World Bank (2021). Children Out of School (\% of Primary School Age).

https://data.worldbank.org/indicator/SE.PRM.UNER.ZS 


\section{Appendix}

ABS: Sectoral Budget Support

BSI: Sectoral Investment Budget

GPE: Global Partnership for Education

FONGIM: International NGO Forum in Mali

AFD: French Development agency

USAID: United States Agency for International Development

PAM: World Food Program

BID: Islamic Development Bank 